\title{
POSTERIOR \\ SHORT SEGMENT \\ STABILISATION WITH \\ INTERMEDIATE SCREWS \\ FOR THORACOLUMBAR \\ FRACTURES- A \\ RADIOLOGICAL \\ EVALUVATION
}

\section{Original Article \\ Orthopaedics}

Dheeraj Kumar $V^{1}$, Mithun Shetty ${ }^{2}$, C. Kunal Kushalappa ${ }^{3}$

1 - Assistant Professor, Department of Orthopaedics, A.J. Institute Of Medical Sciences, Kuntikana Mangaluru

2 - Assistant Professor, Department of Orthopaedics A.J. Institute Of Medical Sciences, Kuntikana, Mangaluru

${ }^{3}$ - Junior Resident, Department of Orthopaedics A.J. Institute Of Medical Sciences, Kuntikana, Mangaluru

Corresponding Author

Dr. Mithun Shetty

Assistant professor,

Department of Orthopaedics

A.J. Institute Of Medical Sciences, Kuntikana,

Mangaluru - 575004

Article submitted on: 05 March 2019

Article Accepted on: 13 March 2019

\begin{abstract}
Introduction: Combined anterior and posterior approaches for instrumentation and stabilisation of all three columns of the spine is the preferred modality for reconstruction of unstable thoracolumbar fractures. However, use of a combined approach on a trauma patient involves significant morbidity. Our study was conducted to evaluate the radiological outcome of decompression and short segment stabilisation with pedicle screws by posterior midline approach for thoracolumbar junction fractures in a single stage.
\end{abstract}

Methods: The present study was a retrospective study conducted in 2018 among 30 patients who underwent short segment pedicle screw fixation for thoracolumbar fractures at tertiary care teaching hospital during the span of 4 years April 2014 to march 2018. Patients with multiple level fractures were not included in the study. Data on age, sex, surgical technique, radiological and clinical outcome were reviewed retrospectively.

Observation: The study showed significant correction of kyphotic angle with a pre op mean value of 15.26 degrees to postoperatively mean value of 6.60 degrees. At final follow up, the mean kyphotic angle was 7.01 degrees. The average vertebral height was significantly corrected from preoperative mean value of $1.6 \mathrm{lcm}$, to a postoperative mean value of $2.20 \mathrm{~cm}$. At final follow up mean value of vertebral height was $2.07 \mathrm{~cm}$. There was no significant complication like screw breakage, screw back out and infection in any of the subjects at final follow up.

Conclusion: Adequate correction of kyphotic angle and vertebral height of unstable thoracolumbar injuries can be obtained and maintained with the use of short-segment pedicle screw fixation including the fractured vertebra, thereby avoiding the need for anterior reconstruction. Stabilisation by single stage posterior approach is a safe and biomechanically reliable method for treating thoracolumbar fractures.

Keywords: Intermediate Screws, Thoracolumbar Fractures, Posterior Fixation, Short Segment Stabilisation 


\section{Introduction}

Surgical management of thoracolumbar fractures involves posterior stabilisation, with pedicle screws at the levels immediately adjacent to the fractured level. Progressive loss of fracture reduction and screw breakage have been associated with this method due to the deficient anterior column ${ }^{1,2,3}$.

Various methods to reconstruct the anterior column by direct anterior reconstruction have been advocated, which in the setting of acute trauma can be associated with significant morbidity.

To prevent failure of implantation via posterior surgeries, increasing the number of levels of fixation along the posterior construct \& using screws at the level of the fracture has been preferred $^{4}$. Addition of a screw at the fractured level, in a short-segment fixation increases the stiffness of the construct and protects the anterior column during loading which could

\section{Results}

Table 1 Gender

\begin{tabular}{|l|c|c|}
\hline & Frequency & Percent \\
\hline Male & 27 & 90.0 \\
\hline Female & 3 & 10.0 \\
\hline Total & 30 & 100.0 \\
\hline
\end{tabular}

Table 1 shows the gender distribution for our study consisting of 27 males and 3 females

Table 2 Age

\begin{tabular}{|l|c|c|c|c|}
\hline & Count & Percentage & Male & Female \\
\hline$<20$ Years & 2 & 6.666667 & 1 & 1 \\
\hline 20 - 30 Years & 4 & 13.33333 & 4 & - \\
\hline 31 - 40 Years & 10 & 33.33333 & 9 & 1 \\
\hline 41 - 50 Years & 7 & 23.33333 & 6 & 1 \\
\hline $50-60$ Years & 7 & 23.33333 & 7 & - \\
\hline
\end{tabular}

Table 2 shows the age distribution for the study which showed majority of the patients to be between 31- 50 years. The distribution of the patients based on gender in each age group has been depicted in the table.
Third section was on preoperative radiological evaluation and the fourth section was on post operative radiological evaluation.

\section{Ethical consideration}

Ethical principles were followed during the collection of data for the following study. The protocol and study details were submitted to the institutional ethics committee and clearance was obtained for the same. Medical superintendent of the hospital was informed regarding the study and permissions were obtained to access the records and details of the patients. All measures were taken to maintain the confidentiality of the patient.

\section{Statistical analysis}

Statistical package for social sciences (SPPS version 11.5; SPSS Inc.,233 South Wacker Drive,11th floor, Chicago, IL. 60606-6412).

Table 3 Mode of injury

\begin{tabular}{|l|c|c|}
\hline & Frequency & Percent \\
\hline $\begin{array}{l}\text { Fall from } \\
\text { height }\end{array}$ & 21 & 70.0 \\
\hline RTA & 9 & 30.0 \\
\hline Total & 30 & 100.0 \\
\hline
\end{tabular}

Table 3 depicts the mode of injury for patients in our study and showed fall from height to be the reason foe majority of the injuries

Table 4 Level of Fracture

\begin{tabular}{|l|c|c|}
\hline & Frequency & Percent \\
\hline D11 & 2 & 6.7 \\
\hline D12 & 10 & 33.3 \\
\hline L1 & 18 & 60.0 \\
\hline Total & 30 & 100.0 \\
\hline
\end{tabular}

Table 4 shows the distribution of the fractured vertebra levels amongst the thoracolumbar junction vertebra in our study 
Table 5 Fracture type

\begin{tabular}{|l|c|c|}
\hline & Count & Percentage \\
\hline Chance Fracture & 2 & 6.666667 \\
\hline Flexion Distraction & 3 & 10 \\
\hline Stable Burst & 7 & 23.33333 \\
\hline Translation & 3 & 10 \\
\hline $\begin{array}{l}\text { Unstable } \\
\text { Burst }\end{array}$ & 12 & 40 \\
\hline $\begin{array}{l}\text { Wedge } \\
\text { Compression }\end{array}$ & 3 & 10 \\
\hline
\end{tabular}

Table 5 shows the distribution of fracture types according to Mcafee et al classification which were diagnosed via preoperative radiographs, $\mathrm{CT}$ and MRI scans.

Table 6 Asia Score

\begin{tabular}{|l|c|c|}
\hline \multicolumn{1}{|c|}{ Asia Scoring } & Number Of Patients (N) & Percentage(\%) \\
\hline Asia A & 2 & 6.67 \\
\hline Asia B & 2 & 6.67 \\
\hline Asia C & 4 & 13.33 \\
\hline Asia D & 5 & 16.67 \\
\hline Asia E & 17 & 56.67 \\
\hline
\end{tabular}

The above table depicts the distribution of patients in our study based on the pre-op neurological status based on ASIA scoring and shows majority of the patients to be ASIA E $(n=17)$, followed by the ASIA D(n=5), ASIA C $(n=4)$ and ASIA A \& B $(n=2)$

Table 7 Kyphosis

\begin{tabular}{|l|l|l|l|l|l|l|}
\hline & N & Mean & $\begin{array}{c}\text { Std. } \\
\text { Deviation }\end{array}$ & Median & \multicolumn{2}{|c|}{} \\
\hline & & & & & \multicolumn{1}{|c|}{$\begin{array}{c}\text { Friedman } \\
\text { test p value }\end{array}$} & \\
\hline Preop & 30 & 15.26 & 3.95 & 14.40 & .000 & HS \\
Postop & 30 & 6.60 & 5.03 & 6.55 & & \\
\hline 6M & 30 & 7.01 & 5.39 & 6.20 & & \\
\hline
\end{tabular}

Table 7 depicts the mean of angle of kyphosis in the preoperative period, postoperative period and final follow up ,showing significant reduction of kyphosis in the immediate postoperative period and mild progression in the postoperative period

Table 8 Vertebral height

\begin{tabular}{|c|l|c|c|c|c|}
\hline & & $\mathbf{N}$ & $\begin{array}{c}\text { Mean } \\
(\mathbf{c m})\end{array}$ & $\begin{array}{c}\text { Std. } \\
\text { Deviation }\end{array}$ & \multirow{2}{*}{ P value } \\
\hline \multirow{3}{*}{ VH } & Preop & 30 & 1.61 & .45 & .000 \\
\cline { 2 - 5 } & Postop & 30 & 2.20 & .38 & HS \\
\cline { 2 - 5 } & $6 \mathrm{M}$ & 30 & 2.07 & .32 & \\
\hline
\end{tabular}

Table 8 depicts the preoperative and postoperative correction of the vertebral height observed during the study and shows significant restoration of vertebral body height via the mean in the postoperative period and mild loss of vertebral height at final follow up

\section{Discussion}

The thoracolumbar junction is a common site of spinal injury occurring in an estimated $6 \%$ of patients experiencing trauma ${ }^{6}$. More commonly occurs in the younger population and in more than $50 \%$ of the cases of thoracolumbar trauma, spinal fractures affect the thoracolumbar junction ${ }^{7}$. These types of injuries are best treated by vertebral column decompression and stabilization ${ }^{8}$. The management plans differ among many of the researchers regarding non-operative $e^{9,10}$ and operative ${ }^{11,12}$ approaches.

The thoracolumbar junction is composed of the zone between the rigid thoracic and the mobile lumbar spine. Vertebral fractures in this transitional area are generally extremely unstable and the kyphotic deformity recorded is of significant degree ${ }^{3}$. Traditionally, stabilisation two levels above and two levels below the fractured segment provided adequate fixation.

Advantages of short-segment posterior stabilization of the injured vertebral motion segments include the familiarity and simplicity of the approach and lesser complications as compared with anterior surgeries. The technique obviates the need for vertebral body augmentation techniques and anterior vertebral reconstruction.

Being a posterior short-segment fixation, the surgical time, blood loss, extensor muscle denervation, cost incurred and overall morbidity in this technique will be much less than a long segment technique or a combined anterior and posterior fixation .But this technique has been criticized because of the risks of implant failure and progression of symptomatic kyphosis. This was attributed mainly to the defective anterior weight bearing column of the spine 
Majority of the patients in our study were young. Out of 30 cases, 27 (90\%) were male and $3(10 \%)$ were females. Raja $^{8}$, in his study showed $86 \%$ of his patients in his series of 50 patients to be male patients. K Khujrekar et $\mathrm{al}^{13}$ in their study on demographics for thoracolumbar fracture found incidence to be eight times more common in males compared to females. Similarly, as per findings in other studies males are more prone to trauma than females ${ }^{3,14}$.

The mean age of patients for our study was around 38.96 years (age range 18-58 years). According to results from many studies it is proven that young people suffer spinal injuries more often than any other age group. Fall from height was the most common cause of injury in $21(70 \%)$ cases which has also been observed in other studies ${ }^{10,13}$.

Most common vertebral body to be fractured was found to be L1 $(60 \%)$ as per our study ,followed by D12 (33.33\%) and D11 (6.7\%). This particular finding was similar to findings of Md. K Ahsan et a ${ }^{15}$ which found $\mathrm{L} 1(44.2 \%)$ to be the most commonly affected level followeSd by D12 (32.7\%). Other studies like K Khujrekar ${ }^{11}$, Shah et $\mathrm{al}^{16}$ and Hitchon et $\mathrm{al}^{17}$ also showed the common level of injury to be D12-L1.

The preoperative neurologic status of the patient was evaluated using ASIA scoring and majority of the patients $(n=17)$ were ASIA E ,without any significant neurological deficits with intact bowel and bladder sensation.

In our study all the post operative and final follow up $\mathrm{x}$ rays were evaluated meticulously and were interpreted to show good correction of kyphotic deformity and adequate restoration of vertebral height. The mean preoperative kyphotic angle was 15.26 degrees which was corrected postoperatively to 6.60 degrees. Final follow up at 6 months showed the mean kyphotic angle to be 7.01 degrees. These results were in accordance with the results obtained by other studies ${ }^{18,19,20,21}$. The mean preoperative Vertebral height was 1.61 $\mathrm{cm}$ which was restored postoperatively to a mean value of $2.20 \mathrm{~cm}$. At final follow up, the mean vertebral height was $2.07 \mathrm{~cm}$ which didn't affect the clinical outcome of the patient in any sort. Results of the restoration of vertebral height were similar to studies by Farrokhi et $\mathrm{al}^{18}$, Kanna et $\mathrm{al}^{20}$ and Tian JW et al ${ }^{22}$.

In the time series graphs constructed for the particular study, based on age, the average correction of kyphosis angle and the average correction of vertebral height(Fig 1 $\& 2$ ), (Table $9 \& 10$ ) was found to be better in patients of younger age group which could be attributed the good bone stock found in young individuals compared to the older age group.

Based on gender, the average correction of kyphosis was found to be better in cases of females as compared to males (Fig 3; Table 11). In case of correction of vertebral height based on gender (Fig 4; Table 12), the immediate average postoperative correction was almost similar in both genders, but at final follow up females did tend to lose the regained vertebral height compared to males, which could be attributed to the poor bone stock in females compared to males. But this did not lead to progression of kyphosis or implant failure in any of the cases.

There were certain limitations to our study. Long term follow up studies are needed to prove the efficacy of stabilisation with intermediate screws. A larger sample size would help establish the efficacy of posterior stabilisation with intermediate screws.

\section{Conclusion}

The findings of the present study indicates that even in fractures with severe kyphosis and loss of vertebral height at the thoracolumbar junction, short segment stabilisation with intermediate screws at the fractured vertebra level provides good clinical and radiologic outcomes.

\section{Figures}

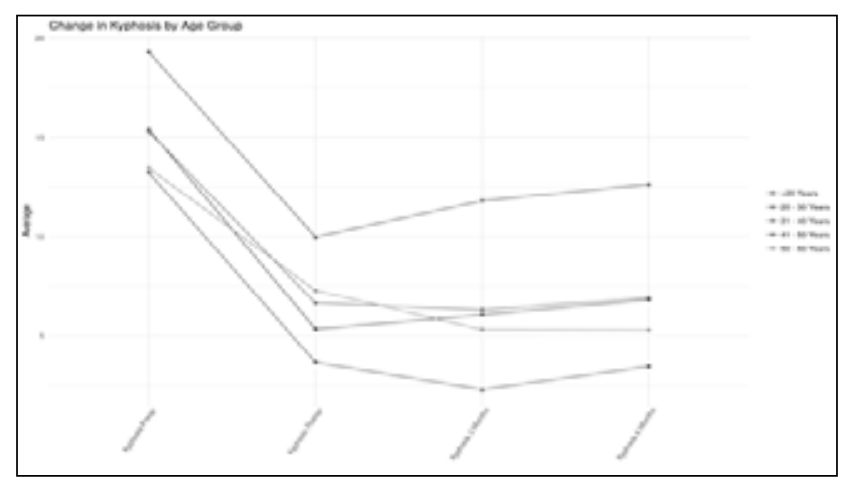

Fig 1: Change In Kyphosis By Age Group 
Table 9

\begin{tabular}{|c|l|c|c|c|c|}
\hline S.N. & Age Group & Kyphosis Preop & Kyphosis Postop & Kyphosis 3 Months & Kyphosis 6 Months \\
\hline 1 & $<20$ Years & 13.2 & 3.65 & 2.3 & 3.45 \\
\hline 2 & $20-30$ Years & 19.25 & 9.97 & 11.78 & 12.62 \\
\hline 3 & $31-40$ Years & 15.37 & 5.33 & 6.05 & 6.79 \\
\hline 4 & $41-50$ Years & 15.26 & 6.64 & 6.29 & 6.89 \\
\hline 5 & $50-60$ Years & 13.43 & 7.27 & 5.3 & 5.27 \\
\hline
\end{tabular}

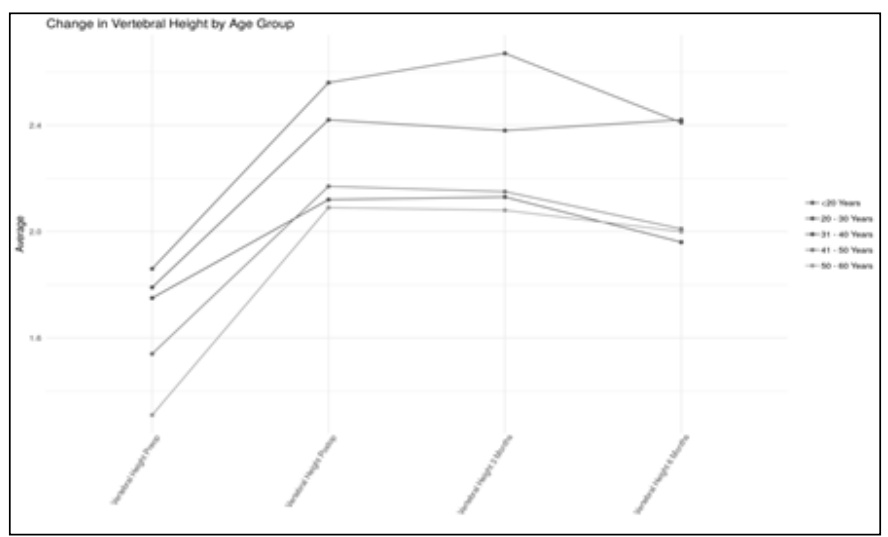

Fig 2: Change In Vertebral Height By Age Group

Table 10

\begin{tabular}{|c|l|c|c|c|c|}
\hline S.N. & \multicolumn{1}{|c|}{ Age Group } & $\begin{array}{c}\text { Vertebral Height } \\
\text { Preop }\end{array}$ & $\begin{array}{c}\text { Vertebral Height } \\
\text { Postop }\end{array}$ & $\begin{array}{c}\text { Vertebral Height } \\
\text { 3 Months }\end{array}$ & $\begin{array}{c}\text { Vertebral Height } \\
\text { 6 Months }\end{array}$ \\
\hline 1 & $<20$ Years & 1.86 & 2.56 & 2.67 & 2.41 \\
\hline 2 & $20-30$ Years & 1.79 & 2.42 & 2.38 & 2.42 \\
\hline 3 & $31-40$ Years & 1.75 & 2.12 & 2.13 & 1.96 \\
\hline 4 & $41-50$ Years & 1.54 & 2.17 & 2.15 & 2.01 \\
\hline 5 & $50-60$ Years & 1.31 & 2.09 & 2.08 & 2 \\
\hline
\end{tabular}

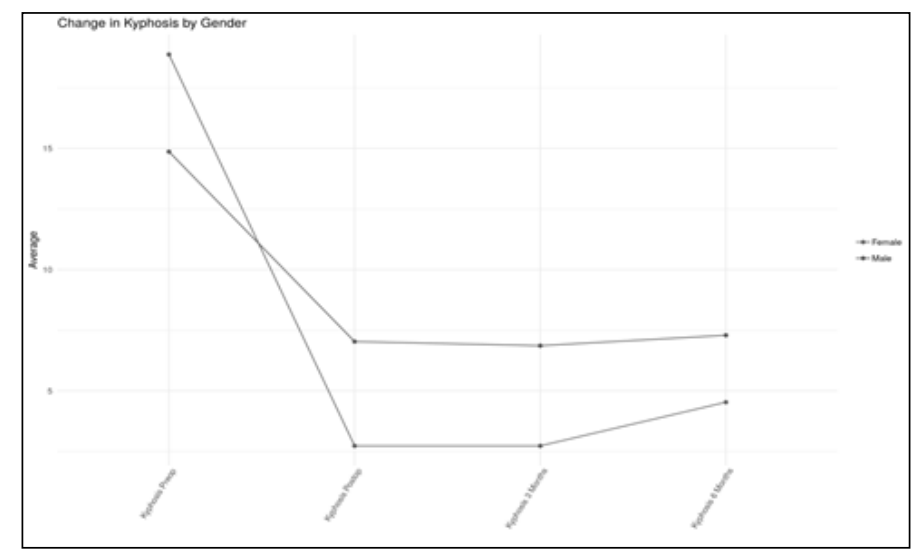

Fig 3: Change In Kyphosis By Gender

Table 11

\begin{tabular}{|c|l|c|c|c|c|}
\hline S.N. & Gender & Kyphosis Preop & Kyphosis Postop & $\begin{array}{c}\text { Kyphosis 3 } \\
\text { Months }\end{array}$ & $\begin{array}{c}\text { Kyphosis 6 } \\
\text { Months }\end{array}$ \\
\hline 1 & Female & 18.87 & 2.73 & 2.73 & 4.53 \\
\hline 2 & Male & 14.86 & 7.03 & 6.86 & 7.29 \\
\hline
\end{tabular}




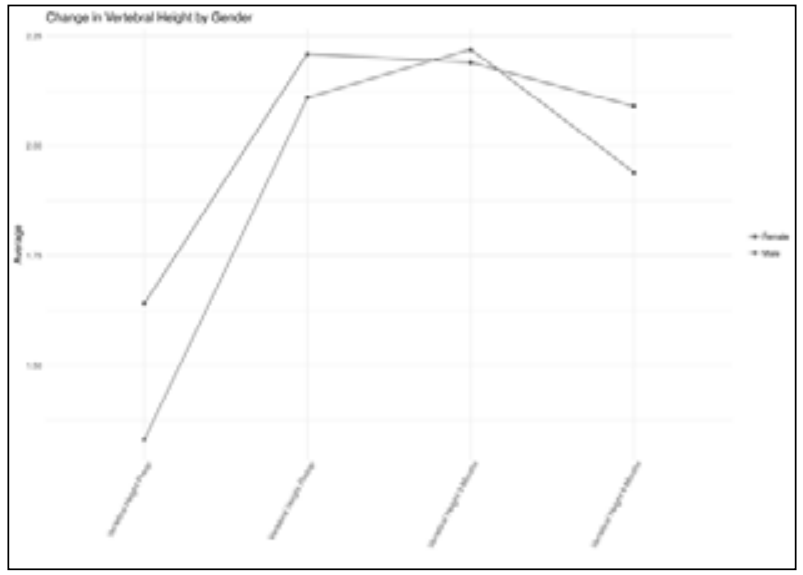

Fig 4: Change In Vertebral Height By Gender

Table 12

\begin{tabular}{|l|l|c|c|c|c|}
\hline Gender & $\begin{array}{c}\text { Vertebral Height } \\
\text { Preop }\end{array}$ & $\begin{array}{c}\text { Vertebral Height } \\
\text { Postop }\end{array}$ & $\begin{array}{c}\text { Vertebral Height } \\
\text { 3 Months }\end{array}$ & $\begin{array}{c}\text { Vertebral Height } \\
\text { 6 Months }\end{array}$ \\
\hline 1 & Female & 1.33 & 2.11 & 2.22 & 1.94 \\
\hline 2 & Male & 1.64 & 2.21 & 2.19 & 2.09 \\
\hline
\end{tabular}

\section{Clinical Photographs}

\section{Case 1}

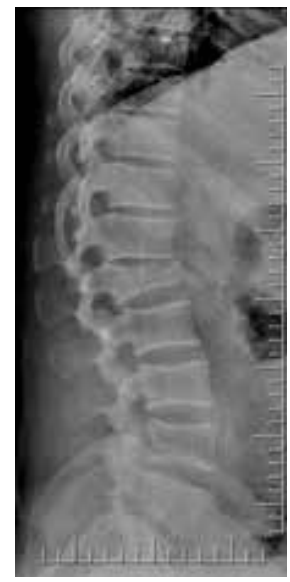

PRE OP

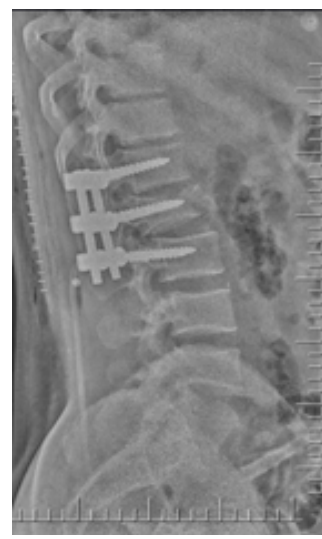

POST OP

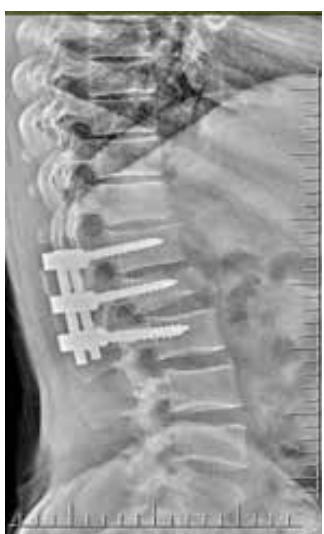

6 MONTHS

Case 2

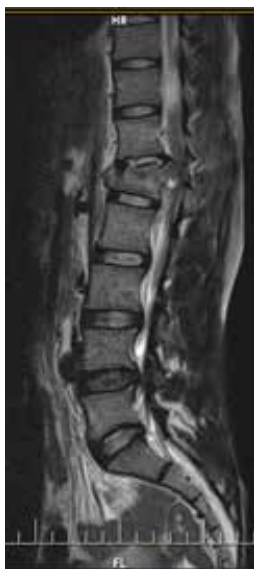

PRE OP

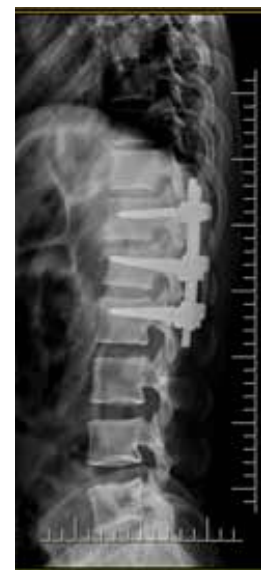

POST OP

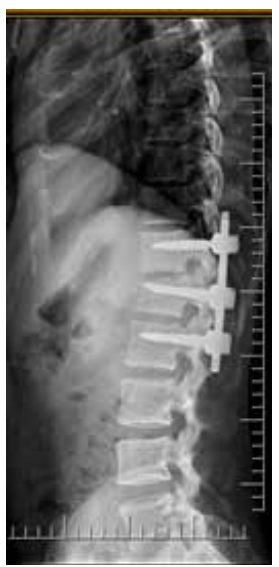

6 MONTHS 


\section{Case 3}

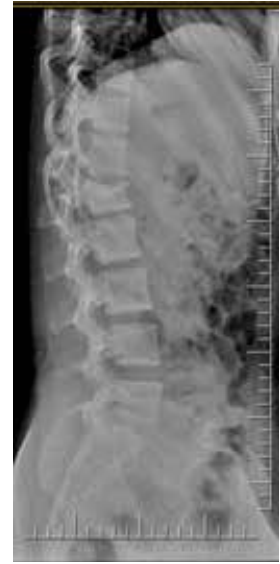

PRE OP

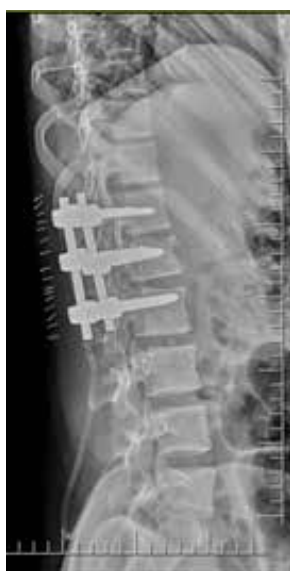

POST OP

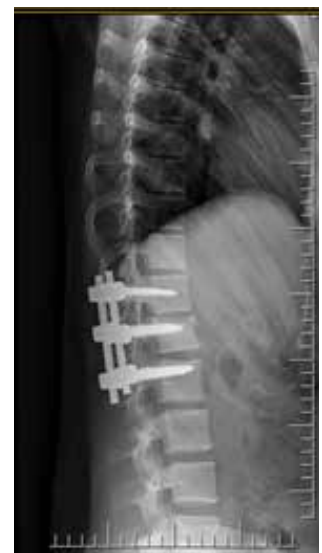

6 MONTHS

\section{References}

1. Benson DR, Burkus JK, Montesano PX, Sutherland TB, McLain RF. Unstable thoracolumbar and lumbar burst fractures treated with the AO fixateur interne. J Spinal Disord 1992;5:335-43.
2. Carl AL, Tromanhauser SG, Roger DJ. Pedicle screw instrumentation for thoracolumbar burst fractures and fracture-dislocations. Spine 1992;17(8 Suppl):S317-24.

3. McLain RF, Sparling E, Benson DR. Early failure of short-segment pedicle instrumentation for thoracolumbar fractures. A preliminary report. J Bone Joint Surg Am 1993;75:162-7.

4. Chiba M, McLain RF, Yerby SA, Moseley TA, Smith TS, Benson DR. Short-segment pedicle instrumentation. Biomechanical analysis of supplemental hook fixation. Spine 1996;21: 288-94.

5. Dick JC, Jones MP, Zdeblick TA, Kunz DN, Horton WC. A biomechanical comparison evaluating the use of intermediate screws and cross-linkage in lumbar pedicle fixation. J Spinal Disord 1994;7: 402-7.

6. Ponnappan RK, Lee JY. Thoracolumbar trauma. In: Orthopaedic knowledge Update 9. Fischgrund $\mathrm{J}$ (ed.). Rosemont, IL, American Academy of Orthopaedic Surgeon, 2008, p 579.

7. Dai LY, Jiang LS, Jiang SD. Posterior short-segment fixation with or without fusion for thoracolumbar burst fractures. J Bone Joint Surg Am. 2009; 91: 1033-41.

8. Raja RA. Management of thoracolumbar spine injuries at a tertiary care hospital. J Ayub Med Coll Abbottabad. 2010; 22: 171-75.

9. Cantor JB, Lebwohl NH, Garvey $\mathrm{T}$, Eismont FJ. Nonoperative management of stable thoracolumbar burst fractures with early ambulation and bracing. Spine 1993; 18: 971-76.

10. Mumford J, Weinstein JN,
Spratt KF, Goel VK. Thoracolumbar burst fractures: The clinical efficacy and outcome of nonoperative management. Spine 1993; 18: 955-70.

11. Jacobs RR, Nordwall A, Nachemson A. Reduction, stability, and strength provided by internal fixation systems for thoracolumbar spinal injuries. Clin Orthop Relat Res. 1982; 171: 300-08.

12. McCullen G, Vaccaro AR, Garfin SR. Thoracic and lumbar trauma: Rationale for selecting the appropriate fusion technique. Orthop Clin North Am. 1998; 29: 813-28.

13. K Khujrekar, S Hadgaonkar, A Kothari, R Raut, V Krishnan, A Shyam, P Sancheti. Demographics of Thoracolumbar Fracture in Indian Population Presenting to a Tertiary Level Trauma Centre. Asian Spine J 2015;9(3):344-351.

14. Gertzben SD, Brown CM, Marks $\mathrm{P}$, et al. The neurologic outcome following surgery for spinal fractures. Spine 1988; 13 : 641-44.

15. Md. K Ahsan, Z Zahangiri, M. A. Awwal, N Zaman, Md. H Haque and A Al Mahmud, Posterior fixation including the fractured vertebra in short segment fixation of unstable thoracolumbar junction burst fractures. BSMMU J 2016; 9: 81-87.

16. Shah AA, Memon IA. Anterolateral decompression for traumatic spinal cord compression. J Pakistan Med Assoc. 1994; 44: 242-43.

17. Hitchon PW, Torner JC, Hadded SS, Follett KA. Thoracic and lumbar fractures. Management analysis. In: Hitchon, Traynelis, Rengachary, Techniques in spi- 
nal fusion and stabilization. New York, Thieme Medical Publishers, 1995, pp 338-44.

18. Farrokhi MR, Razmkon A, Maghami Z, Nikoo Z. Inclusion of the fracture level in short segment fixation of thoracolumbar fractures. Eur Spine J. 2010; 19: 1651-56.

19. Guven O, Kocaoglu B, Bezer M, Aydin N, Nalbantoglu U. The use of screw at the fracture level in the treatment of thoracolumbar burst fractures. J Spinal Disord Tech. 2009; 22: 417-21.

20. Kanna, R. M., Shetty, A. P., \& Rajasekaran, S. (2015). Poste- rior fixation including the fractured vertebra for severe unstable thoracolumbar fractures. The Spine Journal, 15(2), 256-264. doi:10.1016/j.spinee.2014.09.004

21. Wang H, Zhou Y, Li C, et al. Comparison of open versus percutaneous pedicle screw fixation using the sextant system in the treatment of traumatic thoracolumbar fractures. Clin Spine Surg 2014;

22. Tian JW, Wang L, Xia T, et al. Posterior short-segmental fixation combined with intermediate screws vs conventional intersegmental fixation for monosegmental thoracolumbar fractures. Orthopedics 2011;34:e389-96. 